\title{
Analysis Factors Affect of Murabahah Margin in Sharia Commercial Banks in Indonesia
}

\author{
Ainun Nisa \\ Faculty of Economcis, Muhammadiyah Purworejo University \\ Purworejo, Central Java - Indonesia \\ E-mail: ainunnisa0415@gmail.com
}

\begin{abstract}
,
Financing with the murabahah contract becomes the most dominating because murabahah contract is easier to use because it is obvious the split, does not require a complex analysis that benefit both parties between Islamic banks and customers. So that murabahah financing becomes the main product in Islamic banking in Indonesia. The research purpose to analysis and determine a direct effect of operating expense and third fund party to murabahah margin in sharia commercial banks in Indonesia. The period use in this research is 5 years, starting from 2014 to 2018. The type of this research was an causal research to show the direction in the relation between operating expense and third fund party to murabahah margin also to measure the strength of the relation between two or more variables. The population in this research a number of 14 islamic commercial banks that have been and are still registered with the Financial Services Authority in 2014 to 2018. The data analysis technique used in purposive sampling and obtained a sample of 12 islamic commercial banks. The data analysis technique used is multiple linear regression using eviews version 9. The results showed that the operating expense had a negative and significant effect on murabahah margin and third fund party had a positive and significant effect on murabahah margin.
\end{abstract}

Keywords: Murabahab, operating, third party fund

\section{INTRODUCTION}

Financing with the murabahah contract becomes the most dominating because murabahah contract is easier to use because it is obvious the split, does not require a complex analysis that benefit both parties between Islamic banks and customers. So that murabahah financing becomes the main product in Islamic banking in Indonesia. The research purpose to analysis and determine a direct effect of operating expense and third fund party to murabahah margin in sharia commercial banks in Indonesia. The period use in this research is 5 years, starting from 2014 to 2018. The type of this research was an causal research to show the direction in the relation between operating expense and third fund party to murabahah margin also to measure the strength of the relation between two or more variables. The population in this research a number of 14 islamic commercial banks that have been and are still registered with the Financial Services Authority in 2014 to 2018. The data analysis technique used in purposive sampling and obtained a sample of 12 islamic commercial banks. The data analysis technique used is multiple linear regression using eviews version 9. The results showed that the operating expense had a negative and significant effect on murabahah margin and third fund party had a positive and significant effect on murabahah margin. 
Figure 1. Indonesia’s Islamic Banks Financing Revenue

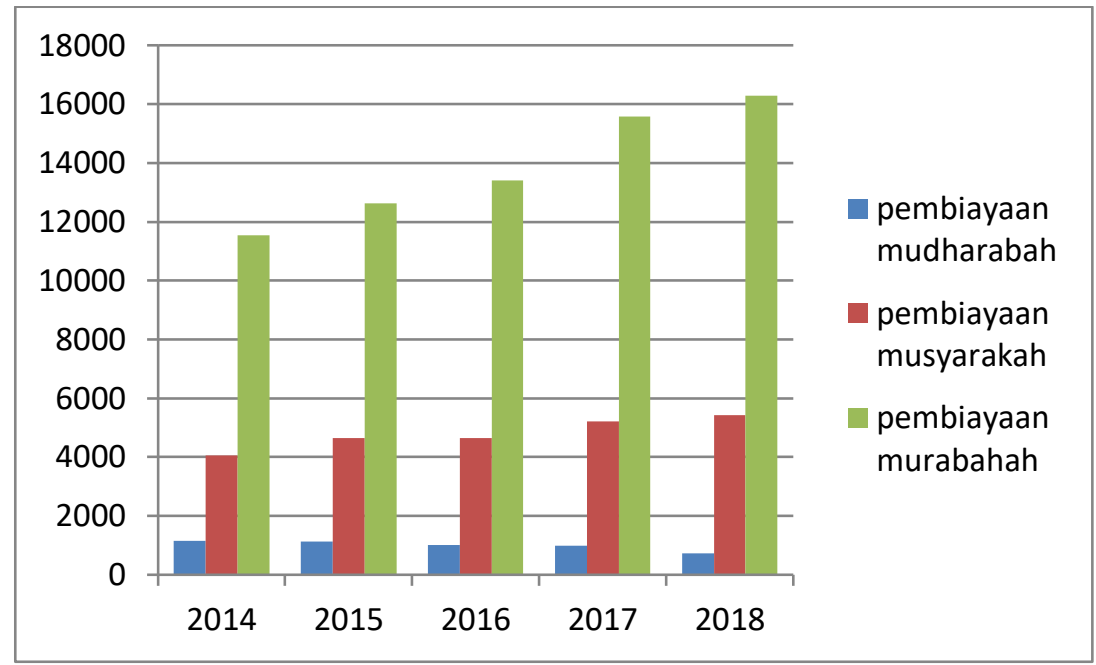

Source: Syariah Banks Statistics 2014-2018

Based on the picture show that financing with the murabahah contract held by all islamic banks in Indonesia until now. This is caused murabahah financing is the financing with the least risk (classified natural certainly contract) where is the flow and financing time has been and the customer as long as the financing runs (Karim,2013:51).

Profit margin is the rate of profit an islamic banks related from selling object murabahah offered by sharia bank to customer. The higher of profit margin obtained by an sharia bank than the greater the ability of sharia bank to distribute financing (Hosen, 2009).

The practice of determining the amount of profit murabahah financing to date based on recommendations and suggestions from Asset and Liability Committee (ALCO) sharia bank, such as Direct Competitor's Market Rate (DCMR), Indirect Competitor's Market Rate (ICMR), expected Competitive Return for Investors (ECRI), Acquiring Cost, and Overhead Cost (Karim,2014:279-280)

In deciding the murabahah margin of sharia bank can do count through two approaches, namely : vegetable approaches and lending rate approaches conventional banking the vegetable approaches, selling cost and profits is the agreement between sharia bank with customer. While lending rate conventional sharia bank using the same method with conventional bank in doing lending rate (Wiroso, 2005:78).

Murabahah margin channeled by sharia bank is influenced by to factors, namely; internal factor and external factor. Internal factor related to poling making and strategy operational bank as third fund party (DPK) and operating cost (BOP). While the external factor (factor from outside the company), comprehend the monetary policy, exchange value fluctuations, inflation rate, interest rate volatility, and finance indtrument innovation.

Third fund party is a funds raised by banks from customer in the form of deposits consisting of mudharabah saving and wadi'ah saving, wadi'ah giro and mudharabah deposit. In raising public fund, sharia bank pay a profit sharing fee or 
bonus on deposits from public. While channeling public funds, sharia bank will be get service fee in the form of profit margin or profit sharing (Ismail, 2011:43). The greater the amount of third fund party, the greater the ability of sharia bank for to do murabahah financing.

Operating costs a cost incurred by bank in operational activity such as labor costs, general administrative cost, depreciation costs, losses asset allowance cost, and other cost associated with bank operational cost or operating cost is all costs incurred by bank in carrying out operations both in raising funds and channeling funds (Wiroso, 2005:90). Based on the description, the researcher is interest in researching the topic "Analysis Factors Affect of Murabahah Margin In Sharia Commercial Bank In Indonesia”.

\section{LITERATURE REVIEW Murabahah}

Financing in the fiqh islam meaning the form of buying and selling certain when the seller an acquisition of goods cost such as price of goods and other cost take to obtain the item and desired rate of profit (Ascarya:2007:82). While in PSAK No. 59 about sharia banking accounting explain that murabahah is a buying and selling contract of goods by stating the acquisition price an profit (margin) agreed by selling and buying. Characteristic from murabahah margin is that selling must provide information to buying about purchase price of product and stated amount the profit added cost.

\section{Murabahah Margin}

The practice murabahah margin rate to sharia bank to financing product based natural ertainly contracts (NCC), that is bisnis contracts which provides payment certainly, both in terms of amount and time (Karim,2013:51). Ascarya (2007:81) state that margin rate which is desired sharia bank can be served in the form a percentage of acquisition cost. The greater of profit margin rate obtained a sharia bank then the greater the ability sharia bank to distribute margin (Hosen, 2009).

\section{Third Party Fund}

Wiroso (2005:7) murabahah margin income the sharia bank receives is one element to be devided with depositor (profit distribution) so that sharia bank will try to improve murabahah margin income which is one income from the management third fund party. The the increases third fund party will be increase revenue sharing that must be given to customer, so that the sharia bank will strive to improve murabahah margin income.

In carrying out activities murabahah financing, sharia bank will be get income margin which is then categorized as operational income. Income margin received by sharia bank for murabahah financing is an element of income included in calculation of the distribution of operating results that will be distributed to fund owner customers (Wiroso,2005:189). 


\section{H1 : third fund party effect on murabahah margin}

\section{Operating Cost}

Cost are expenses incurred by a company in order to create or obtain income. One different between sharia bank and conventional bank is a different in purpose. Conventional bank aims to make a profit while the sharia bank are more interented in fallah. However, in carrying out their duties both as public fund raiser and channel it in the form financing, sharia bank need a cost for finance operational activities. The higher the operational cost incurred show the higher the cost incurred on financing murabahah which can lower murabahah financing margin income. Operational cost needs to be achievement murabahah financing margin, because though sharia bank not aim for profit, however sharia bank have a entity that needs funds to finance operational activities.

$$
\mathrm{H}_{2} \text { : operational cost effect on murabahah margin }
$$

\section{METHODS}

\section{Population and sample}

Population in this research is sharia commercial bank in Indonesia. As many as 14 sharia bank. The sampling technic used this research is nonprobability sampling with technique purposive sampling, the criteria used to select sample in this research as follows :

1. Registered Islamic banks in the financial fervice authority.

2. The bank is al ready registered as a sharia commercial bank in Indonesia until periode 2014-2018.

3. Publish a full annual report periode 2014 to 2018.

Based on these criteria, hed the final amount used in this research is 12 sharia commercial bank.

The data needed in this research is an annual report which has been published by sharia commercial bank and sharia banking statistic was published by financial fercive authority on the official site (OJK) (www.ojk.go.id).

\section{DISCUSSION}

The analysis technic in this research used multiple linear regression analysis technic. As for steps that must be done in multiple linear regression analysis technic before the same regression model is formed is to test the classical assumptions include

\section{Normality Test}

Test normality aims to test whether in the regression model, confounding variable or residual have a normal distribution. How to detect whether in the residual are normally distributed or not that is with Jarque-Bera (JB) test. If the probability value is greater 0,05 then the residual are normally distributed. While if the probability value is smaller 0,05 then the residual are not normally distributed (Ghozali, 2013:160).

2. Multicollinearity Test 
Test multicollinearity aims to test whether in the regression model found a correlation between independent variables. Multicollinearity can be seen from the value tolerance and variance inflation factor (VIF). Measure the variability of selected independent variables that are not explained by other independent variables. Cut off values commonly used to indicate the presence of multicolinearity is tolerance value < 0,10 or same with VIF value $>10$ (Ghozali, 2013:80).

3. Heteroscedasticity Test

Test heteroscedasticity aims to test whether in the regression model inquality occurs variance from residual from one observation to another. How to detect the presence or absence in this research is to use the glacier test. If the probability value the greater 0,05 then heteroscedasticity does not occur. But if the probability value the smaller 0,05 the heteroscedasticity occur (Ghozali, 2013:139).

\section{Autocorrelation Test}

Test autocorrelation aims to test whether in a linear regression model there is a correlation between the disturbance error (residual) in the $t$ period with the disturbance error in the $\mathrm{t}-1$ period (previos). To detect the autoccorrelation can use Durbin-Watson test (DW Test). If the probability value equal to o there is no autocorrelation. While if the probability value not equal to $\mathrm{o}$ then autocorrelation occurs (Ghozali, 2013:110).

The data used in this research were prossed using by software EVIEWS version 9. As for the formula in multiple linear linear regression is as follows :

$$
\mathrm{Y}=\mathrm{a}+\mathrm{b}_{1} \mathrm{X}_{1}+\mathrm{b}_{2} \mathrm{X}_{2}+\mathrm{e}
$$

Where,

$$
\begin{aligned}
& \mathrm{Y}=\text { Murabahah Margin } \\
& \text { a } \quad \text { Constant } \\
& \mathrm{b}_{1}, \mathrm{~b}_{2}, \mathrm{~b}_{3}=\text { Regression Coefficient } \\
& \mathrm{X}_{1} \quad=\text { Third Party Fund } \\
& \mathrm{X}_{2} \quad=\text { Operating Cost } \\
& \mathrm{e} \quad=\text { Error }
\end{aligned}
$$

\section{Classical Assumption Test}

- Normality Test

Figure 1. Normality Graphic

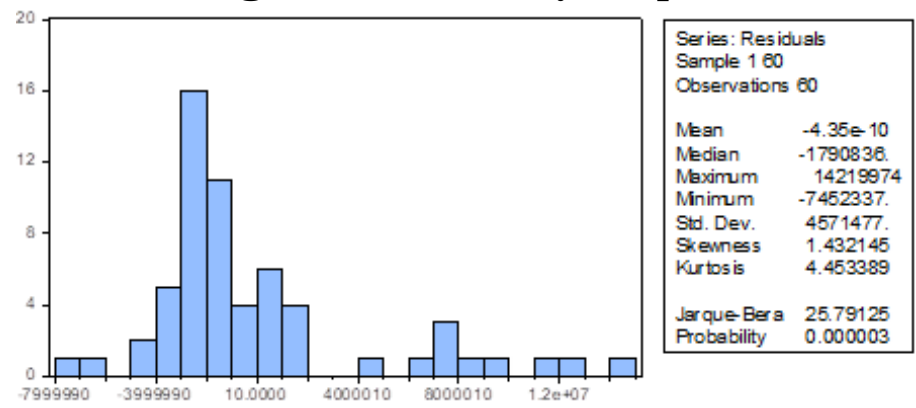

Based on Figure 1, shows that the value Jarque-Bera is equal 25,7 to probability 0,00 . The probability is smaller 0,05 , then the data is not normally distributed. 
- Multicolinearity Test

Table 1. Multicollinearity Test Results

\begin{tabular}{|c|c|c|}
\hline Variable & VIF & Information \\
\hline Third fund party $\left(\mathrm{X}_{1}\right)$ & 1,126901 & Multicollinearity does not occur \\
\hline Operating cost $\left(\mathrm{X}_{2}\right)$ & 1,126901 & Multicollinearity does not occur \\
\hline
\end{tabular}

Based on Table 1, shows that there is no autocorrelation between independent variables because two variable have VIF 1,126901 values the smaller than 10 so it can be concluded that there is no multicollinearity in the two independent variables.

- Heteroscedasticity Test

Table 2. Glejser Test

\begin{tabular}{|c|c|c|}
\hline Variable & Probability & Information \\
\hline Third fund party $\left(\mathrm{X}_{1}\right)$ & 0,0000 & Heteroscedasticity occur \\
\hline Operating cost $\left(\mathrm{X}_{2}\right)$ & 0,5041 & Heteroscedasticity does not occur \\
\hline
\end{tabular}

Based on the table 2 show that third fund party variable have a probability 0,05 , so it can be concluded that there was heteroscedasticity in the research data, while operating cost variable have a probability $>0,05$, so it can be concluded that there was no heteroscedasticity in this research data.

- Autocorrelation Test

Table 3. Autocorrelation Test

\begin{tabular}{|c|c|c|c|}
\hline $\begin{array}{c}\text { Adjust R- } \\
\text { Squared }\end{array}$ & $\begin{array}{c}\text { Std. Error of } \\
\text { Regression }\end{array}$ & Durbin Watson & Information \\
\hline 0,186471 & 4650987. & 0,350925 & Autocorrelation not occur \\
\hline
\end{tabular}

Table 3, show that Durbin Watson value is 0,350925 than compared to durbin Watson table using significant $5 \%$, number of sample $(\mathrm{N})$ is 60 , and number of independent variable $(\mathrm{k})$ is 2 , then produces value $\mathrm{dL}=1,5144$ and $\mathrm{DU}=1,6518$. Durbin ratson value greater than zero and smaller than $1,5144(\mathrm{dL})$, so it can be concluded that the regression equation model doesn't autocorrelation

\section{Hypothesis Testing and Conclusion}

- Multiple Linear Regression Analysis

Table 4. Multiple Linear Regression

\begin{tabular}{|l|l|l|l|}
\hline Model & Coefficients & Probability & Information \\
\hline (Constant) & 24422281, & 0,0061 & \\
\hline DPK & 0,392417 & 0,0002 & Significant \\
\hline BOP & $-1,571639$ & 0,2065 & Not Significant \\
\hline
\end{tabular}

Based on the table 4 obtained multiple linear regression as follows :

Margin Murabahah $=\mathbf{2 4 4 2 2 2 8 1},+0,392417 X_{1}+(-1,571639) X_{2}+e$ 


\section{- Discussion}

1. The effect third fund party on murabahah margin in sharia commercial banks in Indonesia

Table 4 show regression coefficient value third fund party has a positive value $(0,392)$ probability $=0,0002(<0,05)$ is significant, third fund party through the research period effect on murabahah margin.

That result strengthen the theory states that third fund party is a source of funds that can be used by sharia bank in carrying out financing, so it can be concluded the greater fund raised sharia bank then the greater murabahah financing which can be distributed (Kasmir,2012: 67)

2. The effect operating cost on murabahah margin in sharia commercial banks in Indonesia

Table 4 show regression coefficient value operating cost has a negative value $((-1,571)$ probability $=0,20(>0,05)$ is not significant, operating cost through the research period not effect on murabahah margin.

Operating cost not effect on murabahah margin because operating cost less distributed, then decrease of operating cost not accompanied by increased murabahah margin.

\section{CONCLUSION}

Based on the result of research, can be concluded that :

1. Third fund party has a positive and significant effect on murabahah margin.

2. Operating cost has a negative effect on murabahah margin.

\section{REFERENCES}

Achmad, 2018. Analisis Faktor Penjelas Pendapatan Margin Murabahah pada Bank Umum Syariah Di Indonesia. Jurnal Fakultas Ekonomi, 559-568.

Ascarya. 2007. Akad dan Produk Bank Syariah. Jakarta: PT Raja Grafindo Persada.

Dewan Syariah Nasional MUI. 2000. Fatwa DSN Nomor 04/DSN-MUI/VI/2000

Tentang Murabahah. Jakarta : Dewan Syariah Nasional MUI.

Ghozai, Imam. 2013. Aplikasi Analisis Multivariate dengan Program IBM SPSS 20. Semarang. Badan Penerbit Universitas Diponegoro.

Hosen, M. Nadratuzzaman, Jihad. 2009. Faktor-faktor yang Mempengaruhi Permintaan Pembiayaan Murabahah Bank Syariah di Indonesia periode Jamuari 2004 - Desember 2008. Dikta Ekonomi, 6, Nomor 2

Ismail. 2011. Perbankan Syariah. Cetakan Kedua. Jakarta: Kencana Prenada Media Grup

Karim, A. 2013. Bank Islam Analisis Fiqh dan Keuangan. Edisi Keempat. Jakarta: Rajawali Pers.

Kasmir. 2012. Bank dan Lembaga Keuangan Lainnya. Jakarta : PT. Raja Grafindo Persada.

Kasmir. 2014. Bank dan Lembaga Keuangan Lainnya. Edisi Revisi. Jakarta : PT. Raja 
Grafindo Persada.

Kuncoro, Mudrajad. 2003. Metode Riset untuk Bisnis dan Ekonomi. Jakarta: Erlangga.

Otoritas Jasa Keuangan. (2013). Statistik Perbankan Syariah. Jakarta : Otoritas Jasa Keuangan.

Siamat, Dahlan. 2005. Manajemen Lembaga Keuangan "Kebijakan Moneter dan Perbankan”. Jakarta: LPFE-UL.

Wiroso. 2005. Jual beli murabahah. Yogyakarta:UII Press.

Zulpahmi, 2018. Pengaruh Biaya Operasional, Dana Pihak Ketiga (DPK), dan Non Peforming Financing (NPF) terhadap Margin murabahah Pada Bank Umum Syariah di Indonesia. Jurnal Ekonomi \& Keuangan Islam, Vol. 4 No. 2, 81-86. 